\title{
PENDAMPINGAN BIMBINGAN BELAJAR PRAKTIKUM SEDERHANA BERORIENTASIKAN LINGKUNGAN SEKITAR UNTUK ANAK SD PADA MASA PANDEMI COVID-19
}

\author{
N. W. S. Darmayanti'1), ( Wayan Numertayasa2) \\ 1)Program Studi Pendidikan Guru Sekolah Dasar, ITP Markandeya Bali, Bali, Indonesia \\ ${ }^{2}$ Program Studi Bahasa Indonesia ITP Markandeya Bali, Bali, Indonesia \\ Corresponding author: N. W. S. Darmayanti \\ Email: wyndarmayanti@gmail.com
}

Diterima 09 Agustus 2021, Direvisi 14 Agustus 2021, Diterima 14 Agustus 2021

\begin{abstract}
ABSTRAK
Mata pelajaran IPA, sangat sulit diajarkan dalam pembelajaran daring karena pembelajaran IPA di SD perlu menyediakan berbagai pengalaman belajar untuk memahami konsep dan proses IPA. Proses pengajaran materi IPA di SD perlu disertakan dengan melakukan pengamatan atau praktikum. Seperti halnya pernyataan dari beberapa anak-anak SD yang ada di desa Demulih, semenjak covid-19 hanya diberikan materi-materi pelajaran dan tugas-tugas saja oleh guru. Selain itu, siswa diminta mempelajari praktikum yang ada di buku siswa. Anak tersebut kurang paham bagaimana dan apa yang harus dikerjakan terkait praktikum tersebut karena dilakukan di rumah secara mandiri. Orang tua mereka di rumah tidak bisa mengajari anak-anaknya di rumah dikarenakan mereka kurang mengerti terkait praktikum mata pelajaran IPA SD. Kebanyakan dari orang tua anak-anak tersebut bekerja dan waktu untuk membimbing anaknya terbatas. Perlu adanya bantuan pendampingan bimbingan belajar praktikum sederhana berorientasikan lingkungan sekitar. Dengan mempergunakan alat dan bahan yag ada di lingkungan sekitar dapat membantu siswa yang mengalami kesulitan melakukan praktikum pada masa pandemi covid-19. Kegiatan ini dilaksanakan di Dusun Demulih Kecamatan Susut, Kabupaten Bangli. Metode yang digunakan adalah metode ceramah, diskusi, dan praktikum. Keberhasilan kegiatan ini dapat dilihat dari semangat anak-anak SD di desa tersebut dalam mengikuti kegiatan pendampingan. Anak-anak SD yang mengikuti kegiatan sangat aktif bertanya jika ada hal yang mereka belum pahami. Secara keseluruhan mereka sudah mampu melakukan praktikum menggunakan alat dan bahan dari lingkungan sekitar.
\end{abstract}

Kata kunci: bimbingan belajar praktikum; berorientasikan lingkungan sekitar; pandemi covid-19.

\begin{abstract}
Science subjects are very difficult to teach in online learning because science learning in elementary schools needs to provide various learning experiences to understand science concepts and processes. The process of teaching science material in elementary schools needs to be included by conducting observations or practicums. As with statements from several elementary school children in the village of Demulih, since covid-19, the teacher has only been given lesson materials and assignments. In addition, students are asked to study the practicum in the student book. The child does not understand how and what to do regarding the practicum because it is done at home independently. Their parents at home cannot teach their children at home because they do not understand the practicum of elementary science subjects. Most of the parents of these children work and time to guide their children is limited. There is a need for assistance in assisting with simple practical learning guidance that is oriented towards the surrounding environment. Using tools and materials in the surrounding environment can help students who have difficulty doing practicum during the COVID-19 pandemic. This activity was carried out in Demulih Hamlet, Susut District, Bangli Regency. The method used is the lecture, discussion, and practicum method. The success of this activity can be seen from the enthusiasm of the elementary school children in the village in participating in mentoring activities. Elementary school children who participated in the activity were very active in asking if there was something they did not understand. Overall they have been able to do practical work using tools and materials from the surrounding environment.
\end{abstract}

Keywords: practical study guidance; environment-oriented; covid-19 pandemic 


\section{PENDAHULUAN}

Indonesia dikejutkan dengan pandemi virus corona atau dikenal dengan covid-19 (corona virus diseases-19). Sejak social distancing diberlakukan untuk menekan penyebaran Covid-19, pemerintah terus mengimbau masyarakat untuk melakukan segala aktivitas di rumah. Salah satu kebijakan pada bidang pendidikan adalah belajar di rumah yang diterapkan seluruh sekolah dari berbagai tingkatan. Hal tersebut dilakukan karena mengingat bahwa pendidikan berperan penting dalam menciptakan Sumber Daya Manusia (SDM) yang berkualitas. Menurut Ahmadi \& Amri (2011).

Pendidikan bertujuan untuk mengembangkan potensi siswa agar menjadi manusia yang beriman dan bertaqwa kepada Tuhan Yang Maha Esa, berahlak mulia, sehat, berilmu, cakap, kreatif, mandiri, dan menjadi warga negara yang demokratis serta bertanggung jawab. Generasi penerus bangsa harus mempunyai SDM yang berkualitas untuk kemajuan suatu Negara. Pemerintah dalam hal ini berupaya agar guru-guru memberikan pembelajaran berbasis dalam jaringan (daring). Banyak kendala yang ditimbulkan dari pembelajaran daring, terutama pada jenjang Sekolah Dasar (SD). Siswa pada jenjang ini perlu adanya guru sebagai pemantau atau fasilitator secara langsung untuk mengetahui tingkat perkembangan dan pemahaman materi pelajaran.

Penerapan pembelajaran daring memiliki kendala bagi guru SD karena sulit mengontrol dan mengukur sejauh mana pemahaman siswa terhadap materi yang sudah diajarkan. Khususnya pada mata pelajaran IPA, sangat sulit dilakukan dalam pembelajaran daring karena pembelajaran IPA di SD perlu menyediakan berbagai pengalaman belajar untuk memahami konsep dan proses IPA.

Menurut Sri Sulistyorini (2007), proses pembelajaran IPA harus dapat menumbuhkan keaktifan siswa secara penuh dengan cara guru dapat mengemas pembelajaran yang mampu memberi kesempatan pada siswa untuk melaksanakan keterampilan proses seperti: mencari, menemukan, menyimpulkan, mengkomunikasikan sendiri berbagai pengetahuan, nilai-nilai, dan pengalaman yang dibutuhkan.

Proses pengajaran materi IPA di Sekolah SD perlu disertakan dengan melakukan pengamatan atau praktikum karena pelajaran IPA tidak semata-mata belajar hafalan materi atau teori saja (Susanto,2013). Sesuai dengan pernyataan tersebut, kegiatan praktikum sangat perlu dilaksanakan dalam pembelajaran IPA SD. Seperti halnya pernyataan dari beberapa anak-anak SD yang ada di desa Demulih, semenjak covid-19 hanya diberikan materimateri pelajaran dan tugas-tugas saja oleh guru. Selain itu, siswa diminta mempelajari praktikum yang ada di buku siswa. Mereka kurang paham bagaimana dan apa yang harus dikerjakan terkait praktikum tersebut karena dilakukan di rumah secara mandiri. Panduan yang ada di buku terbatas, alat dan bahan pun susah untuk didapatkan sehingga anak-anak menjadi kebingungan.

Hal tersebut perlu bimbingan dan arahan dari orang tuanya di rumah. Namun banyak orang tua yang mengeluh karena tidak bisa mengajari anak-anaknya di rumah dikarenakan mereka kurang mengerti terkait praktikum mata pelajaran IPA SD. Di samping itu kebanyakan dari orang tua anak-anak tersebut bekerja dan waktu untuk membimbing anaknya terbatas.

Berdasarkan permasalahan tersebut, solusi yang tepat ditawarkan adalah dengan adanya bantuan pendampingan bimbingan belajar praktikum sederhana berorientasikan lingkungan sekitar. Sukardi (2002) menyatakan bahwa layanan bimbingan belajar adalah suatu layanan berupa bimbingan yang memungkinkan siswa mengembangkan diri terkait sikap dan kebiasaan belajar yang baik, materi belajar yang cocok dengan kecepatan dan kesulitan belajarnya, serta berbagai aspek tujuan dan kegiatan belajar lainnya, sesuai dengan perkembangan IPTEKS.

Bimbingan belajar praktikum adalah layanan bimbingan belajar praktikum untuk membantu siswa yang kesulitan dan kurang mengerti dalam praktikum IPA. Berorientasikan lingkungan sekitar rumah adalah menggunakan alat dan bahan yang berada di sekitar rumah sehingga mempermudah melakukan kegiatan praktikum.

Praktikum berorientasikan lingkungan sekitar rumah merupakan salah satu cara untuk memanfaatkan alat dan bahan praktikum yg mudah didapat pada kehidupan sehari-hari dilingkungan sekitar. Sesuai dengan penelitian Darmayanti, dkk (2021) yang menunjukkan bahwa motivasi belajar siswa SD pada bidang studi IPA secara keseluruhan berkreteria cukup baik melalui praktikum berorientasikan lingkungan sekitar rumah pada masa pandemic covid-19.

Berdasarkan paparan di atas, maka penulis ingin melaksanakan kegiatan pengabdian pendampingan bimbingan belajar praktikum berorientasikan lingkungan sekitar untuk anak SD pada masa pandemi covid-19.. Kegiatan tersebut dilakukan di sekitar lingkungan rumah yang diberikan kepada siswa untuk mengatasi kesulitan belajar praktikum. 


\section{METODE}

Kegiatan pendampingan ini dilaksanakan pada bulan Mei selama 4 kali di mana setiap minggu dilaksanakan sebanyak 2 kali pertemuan yang disesuaikan dengan keadaan siswa. Adapun tempat pelaksanaan kegiatan adalah bertempat di Dusun Demulih Kecamatan Susut, Kabupaten Bangli. Pendampingan belajar praktikum ini diikuti oleh 10 orang anak-anak SD khususnya anak-anak SD kelas $\mathrm{V}$.

Metode pelaksanaan kegiatan tersebut menggunakan metode ceramah, diskusi dan praktikum dengan pelaksanaan kegiatan dibagi menjadi 4 tahap, yaitu tahap pertama, yaitu tahap pengarahan dan pembagian panduan praktikum. Tahap dua, yaitu tahap penjelasan materi. Tahap ketiga, yaitu tahap praktikum. Selanjutnya terakhir tahap 4 , yaitu tahap diskusi dan presentasi.

\section{HASIL DAN PEMBAHASAN}

Kegiatan pengabdian pendampingan bimbingan belajar praktikum berorientasikan lingkungan sekitar pada masa pandemi covid19 untuk anak SD bertempat di Desa Demulih berjalan dengan lancar sesuai dengan perencanaan. Meskipun terdapat sedikit kendala namun dapat teratasi.

Pelaksanaan kegiatan pendampingan bimbingan belajar praktikum ini ini dibagi menjadi empat tahap, yang pertama tahap pengarahan dan pembagian panduan praktikum dengan menggunakan metode ceramah. Pada tahapan ini anak diberikan pengarahan terkait kegiatan praktikum kemudian dibagikan panduan praktikum. Pada saat pengarahan tersebut anak-anak sangat serius dalam menyimak pengarahan dan ada juga beberapa anak yang bertanya terkait panduan praktikum yang telah dibagikan.

Adapun pelaksanaan tahapan tersebut dapat dilihat pada seperti pada Gambar 1 .

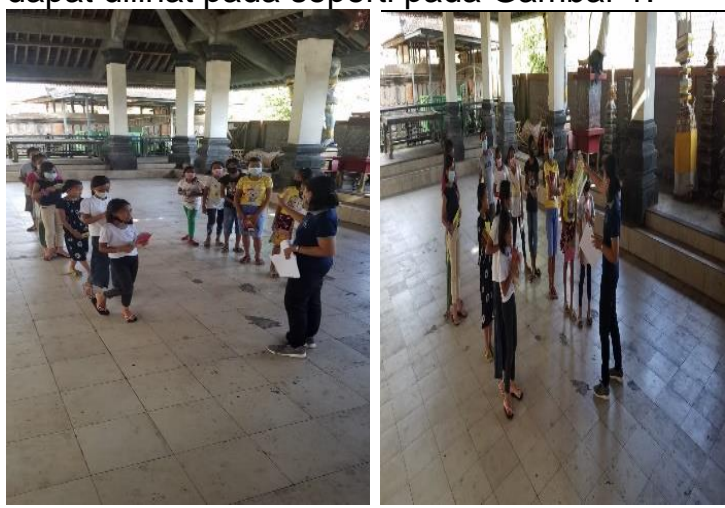

Gambar 1. Kegiatan memberikan pengarahan dan pembagian panduan praktikum

Selanjutnya tahapan kedua, yaitu tahap penjelasan materi. Pada tahapan ini, anak-anak
SD diberikan penjelasan materi terkait apa yang akan dipraktikumkan dan bagaimana proses praktikum dilakukan. Anak yang belum paham terhadap materi praktikum dapat bertanya. Pada saat kegiatan banyak anak-anak yang bertanya terkait materi yang dipraktikumkan bahkan ada beberapa anak yang memberikan usul materi praktikum untuk pertemuan berikutnya. Kegiatan penjelasan materi dapat dilihat pada Gambar 2 berikut.
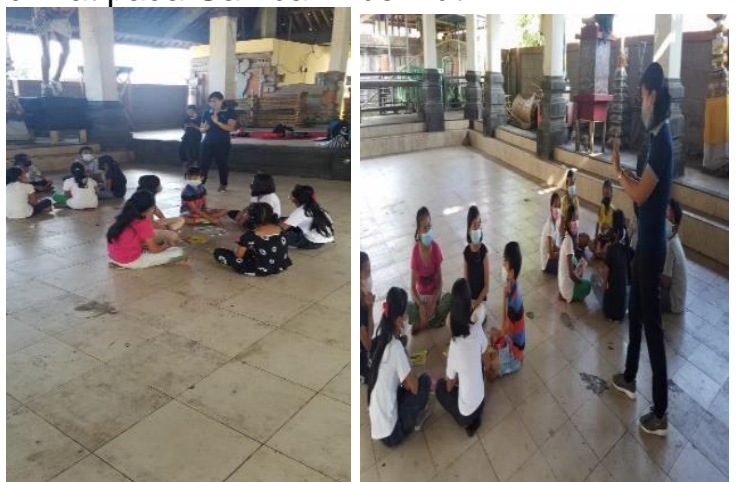

Gambar 2. Kegiatan penjelasan materi

Selanjutnya tahapan praktikum. Pada tahap ini, anak-anak belajar praktikum mulai dari mempersiapkan alat dan bahan sampai mendapatkan hasil. Anak-anak melakukan praktikum sesuai dengan panduan yang diberikan. Alat dan bahan yang digunakan dari lingkungan sekitar rumah yang mudah didapatkan. Saat pelaksanaan praktikum anakanak sangat bersemangat dan aktif juga bertanya terkait langkah kerja dalam praktikum, padahal sudah ada di panduan yang diberikan. Mungkin mereka belum terbiasa dalam melakukan praktikum maka perlu dituntun dengan baik. Secara keseluruhan setelah beberapa kali melakukan pendampingan belajar praktikum, anak-anak mulai dapat melakukan praktikum sendiri. Namun masih tetap perlu sedikit tuntunan. Pelaksanaan kegiatan praktikum terlihat seperti pada Gambar 3.

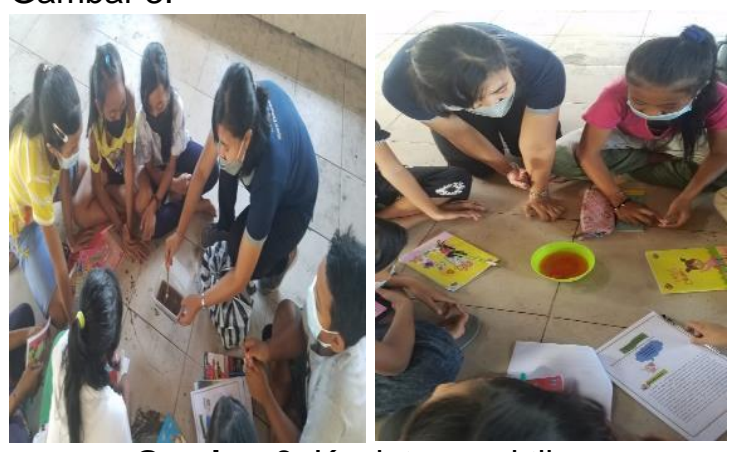

Gambar 3. Kegiatan praktikum

Tahapan terakhir adalah tahapan presentasi dan diskusi. Pada tahapan ini, masing-masing anak menjelaskan hasil praktikum yang diperoleh. Kemudian 
melakukan diskusi terkait materi yang dipraktikumkan. Awalnya anak-anak belum mengerti terkait mempresentasikan hasil yang di dapat dari praktikum. Karena beberapa kali melakukan praktikum dan diskusi maka anakanak mengalami sedikit peningkatkan dalam mempresentasikan hasil dari praktikum. Mereka dapat menyampaikan hasil yang di dapat serta dapat menyimpulkan konsep yang didapat dari praktikum. Anak-anak dalam kegiatan diskusi sangat aktif dan antausias dalam bertanya terkait konsep materi yang belum dimengerti. Adapun kegiatan diskusi dapat dilihat pada Gambar 4.

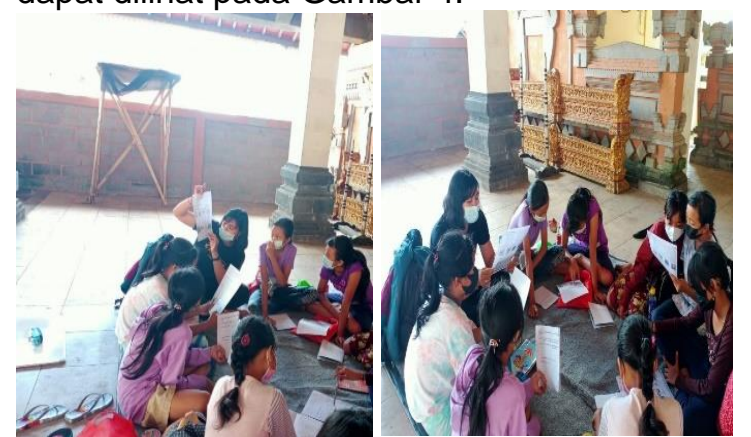

Gambar 4. Kegiatan presentasi dan diskui

Sebagai indikator keberhasilan kegiatan pendampingan bimbingan belajar praktikum sederhana berorientasikan lingkungan sekitar pada masa pandemi covid-19 dapat dilihat dari anak-anak SD yang ikut dalam pendampingan bimbingan belajar praktikum rajin dan serius dalam belajar. Anak-anak tersebut hadir lebih awal ke tempat pendampingan bimbingan belajar praktikum. Selain itu, anak-anak SD yang mengikuti kegiatan aktif bertanya jika ada hal yang tidak dipahami baik pada saat kegiatan praktikum maupun pada saat kegiatan diskusi. Mereka juga tidak malu dalam menyampaikan hasil dari praktikum yang sudah dilakukan. Anak-anak SD yang mengikuti kegiatan ini sudah mampu melakukan praktikum sederhana menggunakan alat dan bahan dari lingkungan sekitar.

\section{SIMPULAN DAN SARAN}

Adapun simpulan yang dapat diambil adalah kegiatan pendampingan bimbingan belajar praktikum sederhana berorientasikan lingkungan sekitar untuk anak SD di Desa Demulih pada masa pandemi covid-19 dapat membantu anak-anak SD yang mengalami kesulitan dalam belajar praktikum. Adapun indikator keberhasilan dari kegiatan ini dapat dilihat dari kehadiran anak-anak tersebut lebih awal ke tempat pendampingan. Selain itu, mereka rajin dan semangat dalam mengikuti kegiatan pendampingan. Anak-anak SD yang mengikuti kegiatan aktif bertanya baik dalam kegiatan praktikum maupun dalam kegiatan diskusi jika ada hal yang mereka belum pahami. Secara keseluruhan mereka sudah mampu melakukan praktikum menggunakan alat dan bahan dari lingkungan sekitar. Pada pelaksanaan kegiatan pengabdian ini berjalan lancar tanpa hambatan yang cukup berarti. Berdasarkan hal tersebut, perlu adanya pendampingan bimbingan belajar praktikum di rumah secara berkesinambungan sebagai upaya membantu siswa yang mengalami kesulitan dalam belajar praktikum.

\section{UCAPAN TERIMAKASIH}

Ucapan terimakasih yang sebesarbesarnya bagi semua pihak yang membantu dalam kegiatan pendampingan kegiatan bimbingan belajar praktikum sederhana berorientasikan lingkungan sekitar untuk anak SD pada masa pandemi covid-19 ini sehingga pelaksanaannya dapat berjalan dengan lancar.

\section{DAFTAR RUJUKAN}

Ahmadi, L. K. \& Amri, S. (2011). paikem gembrot: Mengembangkan Pembelajaran Aktif, Inovatif, Kreatif, Efektif, Menyenangkan, Gembira, Dan Berbobot. Jakarta: Hasil Pustaka.

Darmayanti, N.W.S., Wijaya, W.B., \& Haifaturramah. (2018). Analisis Motivasi Belajar Siswa SD Bidang Studi IPA Di Tengah Pandemi Covid-19 Melalui Praktikum Berorientasikan Lingkungan Sekitar Rumah. Jurnal ELEMENTARY. 4(2) . Hal. 139-143. https://doi.org/10.31764/elementary.v4i 2.4549 .

Sukardi, K, D. (2002). Pengantar Pelaksanaan Program Bimbingan dan Konseling di Sekolah. Jakarta: Rineka Cipta.

Sulistyorini,S. (2007). Pembelajaran IPA Sekolah Dasar. Semarang: Tiara Wacana.

Susanto, A. (2013). Teori Belajar dan Pembelajaran di Sekolah Dasar. Jakarta: Kencana Prenada Media Group. 